\title{
An Analysis of The Imposition of Criminal Sanction to COVID-19 Vaccination Objectors Through the Lens of Criminal Law and Qiyas Shafi'i Mazhab in Indonesia
}

\begin{tabular}{|c|c|}
\hline Info Artikel & Abstract \\
\hline \multirow[t]{2}{*}{$\begin{array}{l}\text { Keywords: } \\
\text { Islamic Law, Criminal Law, } \\
\text { COVID-19 Vaccination, } \\
\text { Criminalization. }\end{array}$} & $\begin{array}{l}\text { This article aims to answer whether vaccination is a right or an } \\
\text { obligation and how criminal law and Qiyas Shafi'i Mazhab views the } \\
\text { basic provisions of criminal law against vaccination objectors. By } \\
\text { combining doctrinal and socio-legal research method, this article } \\
\text { concludes that vaccination is an obligation because a person's personal } \\
\text { right to choose health services, especially COVID-19 vaccination has } \\
\text { turned into a public right. Vaccination is the government's obligation } \\
\text { to protect public health as part of meeting health needs, following the } \\
\text { mandate of the constitution and human rights. According to the } \\
\text { relative punishment theory, the application of criminal sanctions is an } \\
\text { effort made to maintain public order and peace of society, not as a } \\
\text { means of repaying the perpetrator's mistakes. Thus, the sanctions } \\
\text { imposed on the perpetrator are solely to provide fear so that they do not } \\
\text { repeat their actions and other people do not follow them. There are } \\
\text { three main objectives of relative theory, namely prevention, } \\
\text { prevention, and reform. Whereas Qiyas Shafi'i Mazhab puts forward } \\
\text { the application of qiyas as a justification for imposing criminal } \\
\text { sanctions against vaccination objectors. Because a person is prohibited } \\
\text { from doing something that endangers himself and others, punishment } \\
\text { according to the Qiyas Shafi'i Mazhab can be applied. There are } \\
\text { similarities between criminal law and Qiyas Shafi'i Mazhab to a view } \\
\text { of the obligation to vaccinate, that is, both allow the reduction of } \\
\text { individual human rights for the sake of common interests. Ultimately, } \\
\text { this article recommends the need to regulate the handling of COVID- } \\
19 \text { vaccination objectors through act so that vaccination and law } \\
\text { enforcement can run comprehensively, not partially }\end{array}$ \\
\hline & Abstrak \\
\hline $\begin{array}{l}\text { Kata kunci: } \\
\text { Hukum Islam, Hukum Pidana, } \\
\text { Vaksinasi COVID-19, } \\
\text { Kriminalisasi }\end{array}$ & $\begin{array}{l}\text { Artikel ini bertujuan untuk menjawab apakah vaksinasi } \\
\text { merupakan hak atau kewajiban dan bagaimana hukum pidana } \\
\text { dan qiyas mashab shafi'i memandang ketentuan dasar hukum } \\
\text { pidana terhadap penolak vaksinasi. Dengan menggabungkan } \\
\text { metode penelitian doktrinal dan sosio-legal, artikel ini } \\
\text { menvimpulkan bahwa vaksinasi merupakan suatu kewaiban }\end{array}$ \\
\hline $\begin{array}{l}\text { Corresponding Author: } \\
\text { Zaki Priambudi,E-mail: } \\
\text { zakypriambudi@gmail.com }\end{array}$ & $\begin{array}{l}\text { karena hak pribadi seseorang untuk memilih pelayanan } \\
\text { kesehatan, khususnya vaksinasi COVID-19 telah menjadi hak } \\
\text { publik. Vaksinasi merupakan bagian dari kewajiban } \\
\text { pemerintah untuk melindungi kesehatan masyarakat sebagai }\end{array}$ \\
\hline $\begin{array}{l}\text { P-ISSN: 1412-6605 } \\
\text { E-ISSN: } 2301-6426\end{array}$ & $\begin{array}{l}\text { bagian dari pemenuhan kebutuhan kesehatan, sesuai amanat } \\
\text { konstitusi dan hak asasi manusia. Menurut teori pemidanaan } \\
\text { relatif, penerapan sanksi pidana merupakan upaya yang }\end{array}$ \\
\hline
\end{tabular}




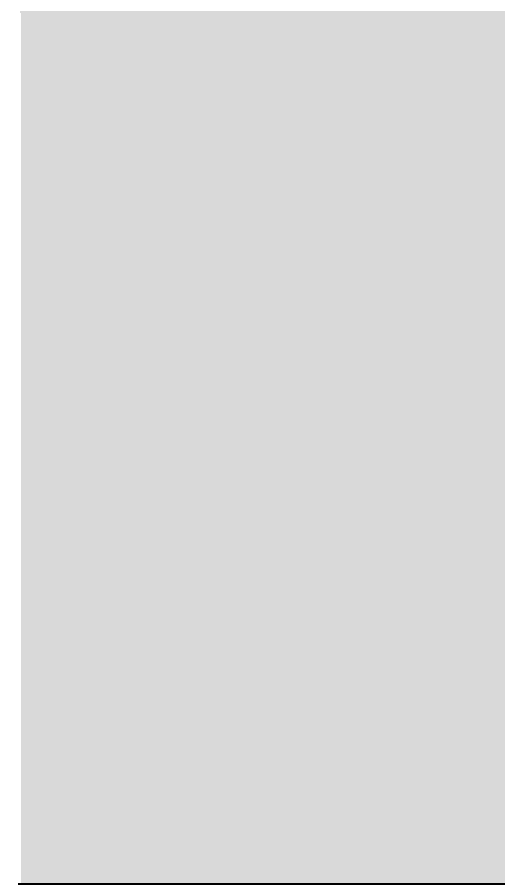

dilakukan untuk menjaga ketertiban dan ketentraman masyarakat, bukan sebagai sarana untuk membalas kesalahan pelaku. Dengan demikian, sanksi yang dijatuhkan kepada pelaku semata-mata untuk memberikan rasa takut agar tidak mengulangi perbuatannya dan orang lain tidak mengikutinya. Terdapat tiga tujuan utama teori pemidanaan relatif, yaitu pencegahan, pencegahan dan reformasi. Sedangkan Qiyas Mazhab Shafi'i memberikan pembenaran sebagai justifikasi pemberian sanksi pidana terhadap penolak vaksinasi. Karena seseorang dilarang melakukan sesuatu yang membahayakan dirinya dan orang lain sehingga sanksi pidana dapat diterapkan. Terdapat persamaan antara hukum pidana dan Qiyas Mazhab Shafi'i dalam pandangan kewajiban vaksinasi, yaitu memungkinkan pengurangan hak asasi individu demi kepentingan bersama. Pada akhirnya, artikel ini merekomendasikan perlunya pergaturan terhadap penanganan penolak vaksinasi COVID-19 melalui Undang-Undang agar vaksinasi dan penegakan hukum dapat berjalan secara komprehensif, tidak parsial.

\section{Introduction}

Since the stipulation of Coronavirus Disease (COVID-19) as a global pandemic by the World Health Organization (WHO) on March 11, 2020, various countries have acted through various policies to reduce the spread of COVID-19 effectively. ${ }^{1}$ Some have succeeded in suppressing transmission rates and rising from adversity, and others are still struggling to suppress the spike in cases that have emerged until now. ${ }^{2}$

Based on data from the COVID-19 Handling Task Force in Indonesia, as of February 14, 2021, 1,217,468 people were confirmed positive for COVID-19, 1,025,273 COVID-19 patients who had recovered, and 33,183 people died due to the Covid virus pandemic. -19 . The Government has made various efforts in Indonesia in reducing the number of cases of death and positive patients, including implementing lockdowns, social distancing, and Large-Scale Social Restrictions (PSBB). In addition, the Indonesian Ulama Council (MUI) issued a fatwa for Muslim communities not to perform worship in mosques to reduce the number of the spread of the COVID-19 epidemic. ${ }^{3}$ However, these efforts are not effective enough to reduce the spread of the COVID-19 virus in Indonesia due to

\footnotetext{
${ }^{1}$ World Health Organization, 'Coronavirus Disease (COVID-19) Pandemic', 2019

<https://www.euro.who.int/en/health-topics/health-emergencies/coronavirus-covid-19/novel-coronavirus2019-ncov> [accessed 8 August 2021].

${ }^{2}$ D. Lewis, 'Why Many Countries Failed at COVID Contact-TracinG but Some Got It Right', Nature, 588.7838 (2020), 384-87 <https://doi.org/https://doi.org/10.1038/d41586-020-03518-4>.

${ }^{3}$ Abdul Kadir Jaelani and others, 'The Impact of Corona Virus on Supply Chain of Halal Tourism Management in West Nusa Tenggara', 9.5 (2020), 823-31.
} 
the low level of public compliance. It is evidenced by the increasing number of positive cases of COVID-19 patients per day and the lack of discipline and public awareness in implementing health protocols. ${ }^{4}$

Other efforts currently being made by the Government to eradicate COVID-19 are through vaccine development research and purchase of vaccine doses as the Government began in early December 2020. A total of 329.5 million vaccines have been ordered by the Government and planning a comprehensive vaccination program for 15 next month. However, the Government also states that vaccination is an obligation for all citizens. If they refuse, they will be subject to imprisonment and fines. The repressive approach taken by the Government has generated debate. The community believes that the imposition of a vaccination program is a form of human rights violation and will make people more reluctant to undergo the COVID-19 vaccination program. ${ }^{5}$ On the other hand, there is an argument that repressive measures are needed as a response to the low level of public compliance with the implementation of health protocols and emergency efforts that education must take to restore the economy for the sake of the public interest. 6

So far, there has been no similar research that has analyzed in depth the convictions of those who refuse COVID-19 vaccination both from the perspective of positive criminal law and qiyas Maqashid sharia. Therefore, this paper seeks to analyze further the basis for the Government to set criminal rules for people who refuse vaccination programs.

To achieving these goals, this paper will be organized as follows. First, this paper will begin with an introduction and research methods. Then, the third part will discuss the status of COVID-19 vaccination, whether it is a right or an obligation, in terms of Human Rights, Positive Criminal Law, and Maqashid Sharia. Furthermore, it will describe the legal basis used by the Government as punishment for rejecting the vaccination program, which will be seen from human rights, positive criminal law, and Maqashid sharia. Finally, the last section will describe the conclusions and follow-up on the ideas that have been described.

\section{Methods}

This paper combines doctrinal and socio-legal research. First, doctrinal research is carried out by looking at existing laws, then followed by a consideration of several issues that affect law and the political practice of the law

\footnotetext{
${ }^{4}$ Bloomberg, 'Indonesia to Punish Those Who Refuse to Take COVID-19 Vaccine', 2021.

${ }^{5}$ Lego Karjoko and others, 'Patent Policy on The Pharmaceutical Sector in Indonesia', 23.5 (2020), 1-13 $<$ https://www.abacademies.org/articles/patent-policy-on-the-pharmaceutical-sector-in-indonesia9670.html>.

${ }^{6}$ Zaidah Nur Rosidah, 'Limitation of Application of Sharia Principles in Sharia Economic Dispute Resolution in Religious Courts Zaidah', Journal of Morality and Legal Culture (JMCL), 1.2 (2020), 93$102<$ https://doi.org/10.20961/jmail.17i1.41087>.
} 
that underlies it. The purpose of this method can lead researchers to initiate a change in law. Next is socio-legal research. This research focuses on the relationship between law and society as an interconnected social phenomenon. Finally, socio-legal research is characterized by a prescriptive model that offers an alternative to the prevailing regulations in society. ${ }^{7}$

Doctrinal research will examine the concept of criminalization against vaccination based on criminal law and Islamic law principles. Meanwhile, sociolegal research is used to analyze regulations and their relationship to other disciplines and other factors that influence law enforcement.

\section{Results and Discussion}

\section{Review of Criminalization against COVID-19 Vaccination in a Criminal Law Perspective}

There are various discourses to question whether COVID-19 vaccination is a right or an obligation? To answer this question, a review of the constitution is required. According to the 1945 Constitution, precisely in Article $28 \mathrm{H}$ paragraph (1), vaccination is a form of fulfilling the Government's obligation to protect public health. Then this is further regulated in Law Number 36 of 2009 concerning Health (Health Law). Article 5 paragraph (3) of the Health Law states that "Every person has the right to independently and responsibly determine the health services that are needed for himself." Furthermore, Article 8 of the Health Law states, "Every person has the right to obtain information about his / her health data, including actions and treatments that he has or will receive from health workers." Then Article 56 paragraph (1) of the Health Law states that "Every person has the right to accept or reject part or all of the relief measures that will be given to him after receiving and understanding the complete information regarding these actions."

However, it should be noted that there is an exception to Article 56 paragraph (1) of the Health Law, namely that the right to accept or reject does not apply to people with diseases whose diseases can quickly spread to the broader community. This provision is contained in Article 56 paragraph (2) letter an of the Health Law. With this, it becomes clear that COVID-19 vaccination is an obligation. ${ }^{8}$

The Government has determined that vaccination is an obligation, so that refusal to vaccinate is considered not complying with the implementation of health quarantine. This is contained in Article 9 paragraph (1) in conjunction with Article 93 of Law Number 6 of 2018 concerning Health Quarantine which

${ }^{7}$ W. H. Chui and M. McConville, Research Methods for Law (Edinburgh: University Press Edinburgh, 2007).

${ }^{8}$ Wulandari Berliani Putri and others, 'Medicolegal Perspective on Physician-Induced Demand Issue', Bestuur, 9.1 (2021), 77-89. 
reads, "Everyone who does not comply with the administration of Health Quarantine as referred to in Article 9 paragraph (1) and obstructs the implementation. Health quarantine causing a Public Health Emergency to be punished with imprisonment of up to 1 (one) year and a maximum fine of Rp. $100,000,000.00$ (one hundred million rupiah)." In addition, this provision is also regulated in Article 14 paragraph (1) of Law No. 4 of 1984 concerning Communicable Disease Outbreaks, which states, "Anyone who deliberately obstructs the implementation of epidemic control as provided for in this law, shall be punished with perpetual imprisonment. One year or a maximum fine of Rp1 million." In this case, the Government establishes public safety as a top priority. It is in line with Cicero's opinion, namely "Salus populi suprena lex exto," which means that people's safety is the highest law for a country. Therefore, the state can show urgent needs concerning the people and legally justifiable reasons for limiting individual rights. ${ }^{9}$

The lack of public awareness of health protocols has led to an increasingly uncontrolled spread of the COVID-19 virus in Indonesia. Based on the survey by the National Level Health Protocol Compliance Monitoring, survey conducted by the COVID-19 Handling Task Force on February 14, 2021. There are $69(15.58 \%)$ of 444 districts/cities, have a level of obedience to maintain distance and avoid crowds of less than 60\%; and 104 (23.48\%) Districts / Cities that have a level of compliance with maintaining distance and avoiding crowds of less than $90 \%$.

In addition, the COVID-19 Task Force also observed the public's compliance with the use of masks. Based on the data obtained from all districts/cities in 34 provinces, there are 28 provinces with average compliance with masks of less than $85 \%$. Referring to the results of the survey, the high percentage of community non-compliance in implementing social distancing and wearing masks increased the spread of COVID-19 and a mortality rate of $8.9 \%$, making Indonesia the highest number of COVID-19 cases in Southeast Asia. ${ }^{10}$ Therefore, punishment is a rational choice to accelerate vaccination in communities with low levels of compliance. Criminalization is supported by three theories: retributive punishment theory, relative punishment theory, and combined theory.

Retributive theory views that the basis for punishment should look at crimes committed by the perpetrators as retaliation for the actions committed by the perpetrators of the criminal acts. According to this theory, the form of

${ }^{9}$ Lina-Mari Laine, 'Parents Decision in Vaccinating the Child and State Obligations from the Perspective of Individual Rights and Community Health with Regard Compulsory MMR-Vaccination Programmes in Europe.' (Åbo Akademi, 2020).

${ }^{10}$ Ministry of Health, 'Monitoring Kepatuhan Protokol Kesehatan Per 14 Februari 2021', 2021

<https://covid19.go.id/storage/app/media/Analisis Data COVID-19 Indonesia/2021/Februari/Monitoring Kepatuhan Protokol Kesehatan per 14 Februari 2021_vPublish.pdf> [accessed 23 March 2021]. 
retaliation provided by the state aims to provide sanctions or suffering as a form of reward (vergelding) to the perpetrator of a criminal act due to the act he has committed and as a preventive measure to prevent the occurrence of similar crimes. In this theory, the philosophy of thinking is, the perpetrator of a crime must be punished for his actions, must not and without bargaining. This theory does not look at what impacts the crime committed or whether the crime harms society; a person should be punished for committing a crime. In terms of the punishment of vaccine rejection, retributive theory views that the vaccine rejection should be convicted of having committed a crime indirectly because their actions endanger the safety of others.

Michael Philips, in The Justification of Punishment and The Justification of Political Authority, argues that this should not be the case. Instead, according to him, a functional criminal theory must use a state justification or justification of the substantial limits on what penalties can be given. ${ }^{11}$

Meanwhile, according to the relative punishment theory, the imposition of crime is not only as retaliation but also as a manifestation of order in people's lives. Reflecting on the opinion of Muladi and Barda N. Arief the theory of punishment relatively justifies the imposition of criminal penalties to prevent someone from committing a crime (nepeccetur), not because someone committed a crime (quia peccatum est). ${ }^{12}$ In other words, the relative punishment theory aims to maintain order in society, not to retaliate for crimes that someone has committed. The theory of punishment has several characteristics, one of which is the enforcement of criminal penalties as an effort to achieve a safe, orderly, and prosperous society. ${ }^{13}$ These characteristics align with government policies that stipulate criminal penalties for people who do not participate in the COVID-19 vaccination program. Therefore, to uphold the safety and welfare of the people, punishment is deemed necessary as a preventive effort for the community not to violate government regulations and carry out a vaccination program to reduce the spread of the COVID-19 virus.

In the perspective of relative punishment theory, the imposition of criminal penalties is an effort made to maintain public order and peace of society, not as a means of repaying the perpetrators' mistakes. Thus, the sanctions imposed on the perpetrator are solely to provide fear so that he will not repeat his

${ }^{11}$ Michael Philips, 'The Justification of Punishment and The Justification of Political Authority', Law and Philosophy, 5 (1986), 393-416 <https://doi.org/https://doi.org/10.1007/BF00240849>.

${ }^{12}$ Barda Nawawi Arief and Muladi, Teori-Teori Dan Kebijakan Pidana, 2nd edn (Bandung: Alumni, 1992).

${ }^{13}$ Barda Nawawi Arief, Beberapa Aspek Kebijakan Penegakan Dan Pengembangan Hukum Pidana (Bandung: PT Citra Aditya Bakti, 2005). 
actions. Thus, there are three main objectives of relative theory: prevention, deterrence, and reformation. ${ }^{14}$

The existence of the objectives of the relative punishment theory and criminal law as a means of social control is in line with government policies that stipulate criminal penalties for people who refuse the COVID-19 vaccination program. In order to uphold the safety and welfare of the people and protect the rights of others to be healthy, punishment for those who refuse the COVID-19 vaccination program is deemed necessary to be implemented as a preventive effort. It creates fear for the community not to violate government regulations to comply with the vaccination program to reduce the spread of the COVID-19 virus in Indonesia. ${ }^{15}$

Next up is the combined theory. The combined theory is a combination of retroactive theory and relative theory. In a combined theory, punishment is to avenge the guilt of a criminal or someone who violates the law and protect the community. On condition, the imposition of a criminal cannot exceed the limit of fair retaliation, and retaliation must be accompanied by rational reasons (Rumadan, 2013). This combined theory is influenced by two sects, including:

a. A theory that focuses on retaliation, but retaliation that has benefits for society. This theory states that punishment is a sanction that has its provisions in the imposition of sanctions, and the imposition of new sanctions is applied if the sanctions have benefits for the public interest;

b. A theory that focuses on the value of community order resilience. This theory views that retaliation is the nature and duty of criminal sanctions. However, in addition to the imposition of retaliatory sanctions, this theory is more inclined towards values to maintain the welfare of society.

Concerning the rejection of the vaccination program, two broad lines can be drawn, namely:

a. Criminalization against vaccination as a sanction, aims to retaliate against a person for his actions against the law;

b. Criminalization against vaccination as a form of protection for the community. At this point, it is intended to provide a sense of security and peace to the community. So that due to the imposition of penalties against vaccination rejectors and sanctions received by the perpetrators, the wider community (who refuse vaccination and do not) has the urge to administer vaccines, and herd immunity can be achieved as well as public health also can be protected.

${ }^{14}$ I Dewa Gede Atmadja and I Nyoman Putu Budiartha, Teori-Teori Hukum. (Malang: Setara Press, 2018).

${ }^{15}$ Devi Triasari, 'Right to Sanitation: Case Study of Indonesia', Journal of Human Rights, Culture and Legal System, 1.3 (2021). 
However, so far, the imposition of criminal charges against those who refuse the COVID-19 vaccination has only been limited to DKI Jakarta Province. This regulation is emphasized in Article 30 of the DKI Jakarta Regional Regulation concerning Corona Virus Disease 2019. which reads, "Every person who deliberately refuses to receive COVID-19 treatment or vaccination, will be punished with a maximum fine of IDR 5,000,000.00 (five million rupiahs)." Thus, every person in question is either an individual or a business entity, both legal and non-legal in DKI Jakarta. Therefore, in its provisions, people who refuse to be vaccinated against COVID-19 can be subject to criminal sanctions in the form of fines. However, the Government needs to regulate the provision of criminal sanctions against those who refuse COVID-19 vaccination thoroughly (nationally) and not partially to accelerate COVID-19 vaccination to restore economic activity to achieve the community's welfare, which had decreased drastically during the COVID-19 pandemic.

It happens because the final goal of determining criminal sanctions is inseparable from the determination of the objectives to be achieved by the overall criminal policy, namely the protection of the community to achieve prosperity. The setting of this goal by Karl O. Christiansen is said to be a fundamental prerequisite. ${ }^{16}$

\section{Review of Criminalization against COVID-19 Vaccination Objectors in the Perspective of Maqashid Sharia}

Maqashid sharia, or the purpose of Islamic law, will be the foundation again when discussing human rights issues from the perspective of Islamic law regarding the punishment of people who refuse vaccination. Because of all the legal provisions mentioned in the Al-Qur'an and As-Sunnah, ijma '; and ijtihad is based on the objectives of Islamic law (maqashid sharia), which is related to the protection of human rights and interests. ${ }^{17}$ Thus, the question of the extent to which the protection of human rights in Islamic law for people who refuse vaccination programs can be answered through an analysis based on the objectives of Islamic law (maqashid sharia).

The description of human rights in Islamic law through the maqashid sharia is the same as the operation of a legal or political system, namely, placing public interests above personal interests. The placement of private interests over public interests must first be ensured that their presence and existence by the state and the state must not violate these rights, which result in the loss of the independence and nobility of a citizen. After the state has recognized that public interests are above personal interests, the description of human rights

${ }^{16}$ K. O. Christiansen, 'Crime in a Danish Twin Population', in Acta Geneticae Medicae et Gemellologiae: Twin Research (Cambridge University, 1970), XIX, 323-326.

${ }^{17}$ T. Santoso, Asas-Asas Hukum Pidana Islam (Jakarta: Raja Grafindo Persada, 2016). 
through the maqashid sharia, which includes religion, life, reason, lineage or dignity, and property, can be carried out. ${ }^{18}$

Vaccination is one of the issues often contested in Islam because there are rumors that the vaccine is made from pork enzymes and contains dangerous chemicals. After that, the issue of vaccines ended with conflicts about herbal medicine with modern medicine and prophetic medicine (tibbun-nabawy) with vaccines. It happens because vaccines are often analogous to something that comes from humans. At the same time, prophetic medicine comes from Allah SWT, one of which is considered correct and the other is considered wrong. ${ }^{19}$

In the Islamic perspective, there is no nasal argument that mentions in detail vaccine treatment, but Islam has two perspectives on the transmission of science. The first is the science of qauliyah which defines this type of knowledge as a knowledge sent down by Allah in the form of revelation to humans through the intermediaries of his prophets and is absolute, general, and functions to live life. Second, the science of qauniyah means that knowledge is passed down in the form of inspiration to a human being who learns about something and is relative, specific, and to complement the means of human life to obtain smooth worship. ${ }^{20}$ The COVID-19 vaccine is a product of qauniyah science. ${ }^{21}$

The absence of nasal or qauliyah arguments about vaccines does not mean that the COVID-19 vaccination is against religious teachings. However, vaccines are knowledge sent down by Allah in inspiration through human intermediaries and scientific research. Therefore, the rejection of vaccines is an understanding that deviates from Islamic teachings due to beliefs that are not based on scientific objectivity and the nature of tabayyun and husnudzon towards vaccines. In fact, in Surah Al-Hujurot, verse 6, people of faith are warned to examine news not to accuse a people and then regret what they have done. In addition, Islam places great importance on prevention if something can involve the life of a servant and the smoothness of worship of a servant. As in the Hadith of Muslim History, which states that "Strong believers are better and loved by Allah than weak believers; and in both, there is goodness" concerning to H.R. Muslim.

${ }^{18}$ Zaidah Nur Rosidah, 'Coherence of the Rules of Sharia Against Pancasila', Bestuur, 8.1 (2020), 40 $<$ https://doi.org/10.20961/bestuur.v8i1.42723>.

${ }^{19}$ M. M. Nasution, 'Vaksinasi Dalam Perspektif Islam', Forum Paedagogik, 10.2 (2018), 61-70.

${ }^{20}$ Nasution.

${ }^{21}$ Resti Dian Luthviati and Suviwat Jenvitchuwong, 'Implementation of Halal Product Assurance in the Pharmaceutical Sector in Indonesia', Journal of Human Rights, Culture and Legal System, 1.3 (2021). 


\section{Fulfillment of the Elements of Criminal Actions against the Vaccination Objectors according to Qiyas Law Method of Istinbat (Excavation)}

The Islamic criminal law system recognizes elements of crime in two parts, namely: general elements and particular elements. These elements will later become material for consideration and the basis that those who reject the vaccination program must first fulfill the elements of a criminal act before punishment can be imposed. ${ }^{22}$ The general elements are divided into three parts, including:

a. Al-Rukn al-Syar'iy (legal element), namely, the existence of an explicit provision or passage and prohibiting an act is accompanied by legal sanctions;

b. Al-Rukn al-Madi (material element), namely, the existence of a criminal act. This criminal act can be in the form of an active act (commission) and passive act/neglect (omission);

c. Al-Rukn al-adabiy (moral element), namely, a criminal offender must be legally competent, including maturity and being held accountable.

The method of extracting the law in the form of qiyas is a law that is popular among the Syafi'i Mazhab. ${ }^{23}$ Syafi'i conceptualized four parts in the definition of the components of sharia which consist of:
a. Al-Qur'an;
b. As-Sunnah;
c. Ijma; and
d. Qiyas.

Shafi'i understands that qiyas is allowed to solve cases not regulated in the Al-Qur'an, As-Sunnah, and ijtihad. Nevertheless, generally, ordinary people only understand qiyas as a form of analogy or a form of looking for similarities in determining a new law even though qiyas is much more complicated and has certain conditions before a case can be qiyas.

Qiyas, according to the point of view of Syafi'i, is the same as ijtihad even according to Syafi'i, between qiyas and ijtihad are two different words but have the same meaning Muhammad bin id. Through qiyas, it means that a mujtahid has returned order or law according to its source, namely, Al-Quran and As-Sunnah Fuad Ijtihad is a necessity in looking for things that contain benefits for humans based on solid suspicions of the opinions and understanding of the mujtahid of an argument. The meaning of benefit, in this case, is anything that can lead humans to obedience to Allah and keep people

${ }^{22}$ Santoso.

${ }^{23}$ Santoso. 
away from immorality Jaya. So, ijtihad carried out in a qiyas manner will produce a new law or order that is reasonable and not only based on ra'y (personal opinion).

According to Abu Zahrah, the principle in qiyas is connecting problems with other problems analogically based on the equation of cause ('illat) and the nature that forms it. If we have found a similarity between the causes and nature of the two problems, the legal consequences must be the same as the original law that was qiykan Fuad. Therefore, ijtihad is obtained can be accounted for because it has been through reasoning based on the text. In the verse of the Al-Quran itself, qiyas becomes the basis for extracting the law. If new problems are found and cause debate, then the case should be returned to the Al-Qur'an and Sunnah as mentioned in the Qur'an Surat An-Nisa' Verse 59.24

Before exploring whether or not the elements of the criminal act against the COVID-19 vaccination program are fulfilled through the qiyas method, the term and pillars of qiyas will be described in advance. Rukun in qiyas is an element that must be fulfilled in advance to assess the validity and perfection of the legal product that will be produced. ${ }^{25}$ If the pillars and conditions in qiyas are not achieved, then qiyas also cannot be applied. Ushul's experts also argue that qiyas is only considered valid when it has fulfilled its pillars. There are four pillars of qiyas, namely:

a. Ashal, namely an old case or law where there is a legal stipulation which is used as a reference contained in the text or ijma;

b. Furu', which is a branch of a case or case to be qiyas-ed which has no legal stipulation on the nasal or conscience but is related to ashal;

c. Hukum contained in the last verse are also stipulated in furu 'because of the similarity of' illat to ashal;

d. Illat, namely legal stipulations that can be understood and known clearly and can be limited or the characteristics contained in ashal that cause the law on furu' (branch).

For more details in deciphering and extracting the law on the position of vaccines with the status of harmonious qiyas, the following table will be exemplified:

Tabel 3.1 The Status of Harmonious Qiyas

\begin{tabular}{llll}
\hline Ashal & Furu' & 'Illat & Hukum \\
\hline
\end{tabular}

${ }^{24}$ Mas Pungky, Hendra Wijaya, and Mohammad Zulfikar Ali, 'Legislation Impediments in Reorganising Government Bodies in Indonesia', Jurnal Bestuur, 9.1 (2021), 1-12.

${ }^{25}$ Luthviati and Jenvitchuwong. 


\begin{tabular}{llll}
\hline $\begin{array}{l}\text { Medicines that } \\
\text { are lawful in }\end{array}$ & $\begin{array}{l}\text { Vaccines, herbal } \\
\text { ingredients, and }\end{array}$ & $\begin{array}{l}\text { Gives the body } \\
\text { resistance to a } \\
\text { general and }\end{array}$ & $\begin{array}{l}\text { Mandatory/Changeable } \\
\text { (can be }\end{array}$ \\
others. & disease or can cure & done/recommended).
\end{tabular}

advice for a disease.

treatment in the

nasal passages.

The arguments and laws stipulated in the ashal are contained in a hadith which reads, "Verily Allah, the Most Holy and Most High, has sent down the disease and its remedy. Therefore, you should seek treatment but do not seek treatment with something that is forbidden" concerning to Hadith by Abu Daud Number 3874. So, the law of medicine in general mentioned in this nasal argument is immutable. However, if a disease is an epidemic, the law changes to become mandatory because it involves the broader public interest. The derivatives or branches (furu') of the treatment mentioned are various kinds, and vaccines are included from the derivatives mentioned in this passage due to the similarity of' 'illat, which is a medium to give the body resistance to a or a medium to cure disease. So, it can be concluded that 'illat and the law function as the cause or legal stipulation of the COVID-19 vaccine because the relationship between 'illat and the law creates a statute of legal equality that applies in ashal.

Vaccine refusal was made furu' because of the similarity of 'illat which is threatening the lives of oneself and others. With someone refusing the vaccine, two possibilities can occur. Namely, that person can be exposed to COVID-19, or that person becomes a person without symptoms and transmits it to other people. So, the act of refusing vaccines is included in the legal provisions, which are in ashal. These extreme activities are life-threatening, and it can be concluded that refusal of vaccines is prohibited and haram based on extracting the law through qiyas.

\section{Conclusion}

The high level of community non-compliance with the application of health protocols is the basis for imposing criminal sanctions against those who refuse COVID-19 vaccination. Then, the convictions follow the mandate of the 1945 Constitution of the Republic of Indonesia, Law Number 4 of 1984 concerning Communicable Disease Outbreak Law, Law Number 36 of 2009 concerning Health, Law Number 6 of 2018 concerning Health Quarantine, and the DKI Jakarta Regional Regulation Number 2 of 2020 concerning Prevention of COVID19. According to the criminal theory, the above legal products are by modern criminal theory, namely the theory of punishment, such as Retributive, relative punishment theory, and combined theory. Meanwhile, according to Islamic law, especially the Shafi'i Mazhab of thought puts forward the application of qiyas as 
a justification for imposing criminal sanctions against those who refuse vaccination. Because a person is prohibited from doing something that endangers himself and others, punishment according to the Shafi'i Mazhab can be applied. Apart from being based on qiyas, punishment for refusing vaccination is also based on maqashid sharia (the purpose of Islamic law). Therefore, the punishment for refusing vaccination is in line with the requirements of qiyas and maqashid sharia. There are similarities between criminal law and Islamic law given the obligation to vaccinate, which is to reduce individual human rights for the sake of common interests.

\section{Refrences}

Arief, Barda Nawawi, Beberapa Aspek Kebijakan Penegakan Dan Pengembangan Hukum Pidana (Bandung: PT Citra Aditya Bakti, 2005)

Arief, Barda Nawawi, and Muladi, Teori-Teori Dan Kebijakan Pidana, 2nd edn (Bandung: Alumni, 1992)

Atmadja, I Dewa Gede, and I Nyoman Putu Budiartha, Teori-Teori Hukum. (Malang: Setara Press, 2018)

Bloomberg, 'Indonesia to Punish Those Who Refuse to Take Covid-19 Vaccine', 2021

Christiansen, K. O., 'Crime in a Danish Twin Population', in Acta Geneticae Medicae et Gemellologiae: Twin Research (Cambridge University, 1970), XIX, 323-326

Chui, W. H., and M. McConville, Research Methods for Law (Edinburgh: University Press Edinburgh, 2007)

Jaelani, Abdul Kadir, I Gusti Ayu, Ketut Rachmi, and Lego Karjoko, 'The Impact of Corona Virus on Supply Chain of Halal Tourism Management in West Nusa Tenggara', 9.5 (2020), 823-31

Karjoko, Lego, Said Gunawan, A L Sentot Sudarwanto, Heriyanti, Zaidah Nur Rosidah, I Gusti Ayu Ketut Handayani, and others, 'Patent Policy on The Pharmaceutical Sector in Indonesia', 23.5 (2020), 1-13 <https:/ / www.abacademies.org/articles/patent-policy-on-thepharmaceutical-sector-in-indonesia-9670.html>

Laine, Lina-Mari, 'Parents Decision in Vaccinating the Child and State Obligations from the Perspective of Individual Rights and Community Health with Regard Compulsory MMR-Vaccination Programmes in Europe.' (Abo Akademi, 2020)

Lewis, D., 'Why Many Countries Failed at COVID Contact-TracinG but Some Got $\begin{array}{llll}\text { It } \quad \text { Right', } \quad \text { Nature, } & 588.7838 \quad \text { (2020), }\end{array}$ <https://doi.org/https://doi.org/10.1038/d41586-020-03518-4>

Luthviati, Resti Dian, and Suviwat Jenvitchuwong, 'Implementation of Halal 
Product Assurance in the Pharmaceutical Sector in Indonesia', Journal of Human Rights, Culture and Legal System, 1.3 (2021)

Ministry of Health, 'Monitoring Kepatuhan Protokol Kesehatan Per 14 Februari 2021', 2021 <https://covid19.go.id/storage/app/media/Analisis Data COVID-19 Indonesia/2021/Februari/Monitoring Kepatuhan Protokol Kesehatan per 14 Februari 2021_vPublish.pdf> [accessed 23 March 2021]

Nasution, M. M., 'Vaksinasi Dalam Perspektif Islam', Forum Paedagogik, 10.2 (2018), 61-70

Philips, Michael, 'The Justification of Punishment and The Justification of Political Authority', Law and Philosophy, 5 (1986), 393-416 <https://doi.org/https:// doi.org/10.1007/BF00240849>

Pungky, Mas, Hendra Wijaya, and Mohammad Zulfikar Ali, 'Legislation Impediments in Reorganising Government Bodies in Indonesia', Jurnal Bestuur, 9.1 (2021), 1-12

Putri, Wulandari Berliani, Widyasari Vita, Juliet Musabula, and Muhammad Jihadul Hayat, 'Medicolegal Perspective on Physician-Induced Demand Issue', Bestuur, 9.1 (2021), 77-89

Rosidah, Zaidah Nur, 'Coherence of the Rules of Sharia Against Pancasila', Bestuur, 8.1 (2020), 40 <https://doi.org/10.20961/bestuur.v8i1.42723>

- - -, 'Limitation of Application of Sharia Principles in Sharia Economic Dispute Resolution in Religious Courts Zaidah', Journal of Morality and Legal $\begin{array}{lllll}\text { Culture } & \text { (JMCL), } & 1.2 & \text { (2020), } & \text { 93-102 }\end{array}$ <https://doi.org/10.20961/jmail.17i1.41087>

Santoso, T., Asas-Asas Hukum Pidana Islam (Jakarta: Raja Grafindo Persada, 2016) Triasari, Devi, 'Right to Sanitation: Case Study of Indonesia', Journal of Human Rights, Culture and Legal System, 1.3 (2021)

World Health Organization, 'Coronavirus Disease (COVID-19) Pandemic', 2019 <https://www.euro.who.int/en/health-topics/healthemergencies/coronavirus-covid-19/novel-coronavirus-2019-ncov> [accessed 8 August 2021] 